\title{
CORROSION CHARACTERISTICS OF AL-0.91Mg-0.55Si-1.12Fe-0.39Ca
}

\section{AL-ALLOY AGED AT ELEVATED TEMPERATURE IN $0.8 \mathrm{MH}_{2} \mathrm{SO}_{4}$ SOLUTION}

\author{
Suresh Chand ${ }^{1}$, Madhusudhan $D^{2}$ \\ ${ }^{1}$ Lecturer, Dept. of Metallurgical and Materials Engineering, RGUKT IIIT Nuzvid, A. P, India \\ ${ }^{2}$ Lecturer, Dept. of Metallurgical and Materials Engineering, RGUKT IIIT Nuzvid, A. P, India
}

\begin{abstract}
The study of degradation of Al-0.91Mg-0.55Si-1.12Fe-0.39Ca aluminum-alloy is carried out under different state of microstructure. The reason for this work is to decide the impact of heat treatment on the microstructure and the corrosive consumption of Al-alloy in acid utilizing weight reduction system. Specimens were solution treated at $545^{\circ} \mathrm{C}$ and artificially aged at $185^{\circ} \mathrm{C}$. The maximum hardness is found after aging for $12 \mathrm{hrs}$. They were immersed in 0.8 molar solution of sulfuric acid for $0.58 \mathrm{hrs}, 1.08 \mathrm{hrs}, 1.58,2.08 \mathrm{hrs}$ and $2.58 \mathrm{hrs}$. The corrosion rates were calculated for various immersion periods. The test work has uncovered that time and temperature assumes an imperative part in the precipitation transformation procedure of the Al-ally. The hardness increases due to formation of second phase particles of $\mathrm{Mg}_{2} \mathrm{Si}$. In over-aging of the alloy, the growth of the precipitate particle takes place at the expense of smaller precipitate particles. The rate of corrosion is found lower in the artificially aged specimen. The corrosion rates are found stabilized after 2.08 hrs of immersion in $\mathrm{H}_{2} \mathrm{SO}_{4}$. The X-Ray Diffraction patterns are also analyzed in the range of $10-80^{\circ}$ which are showing peaks of aluminum solid solution and $\mathrm{Mg}_{2} \mathrm{Si}$ in the different patterns.
\end{abstract}

Key Words: Corrosion rate, Aluminum alloys, aging of alloy, solutionizing, acid, weight reduction.

\section{INTRODUCTION}

Aluminum has following been distinguished as the most widely recognized metal on earth, framing around eight percent of the world's covering. Aluminum alloys has been used extensively for several applications. Al-alloy is used in pipe railing, medical equipment, marine applications, machine parts, furniture, architectural extrusion, automotive parts, building products, electrical and electronic applications [1]. The requirement of $6 \mathrm{XXX}$ Al-alloys has been ever growing in automotive, aero space, and marine structures due to their high specific strength, improved mechanical and corrosion resistance properties [2-3]. The sequence of the transformation during aging is as follows. Supersaturated solid solution $\rightarrow \mathrm{GP} \rightarrow \theta^{\prime \prime} \rightarrow \theta^{\prime} \rightarrow \theta$. The restricted degradation of Al-alloy in fluid chloride arrangements has been examined utilizing distinctive systems [4-8]. The conventional surface designing strategies, for example, chromate (hexavalent Chromium) plating had been utilized successfully on surface of aluminum at the lowest cost. However, the european group bans those putting on their business sector for new electrical furthermore electronic instruments holding more than the suitable levels for hexavalent chromium, lead.[9]. There something like that a lot of people publications endeavoring on the structure about disintegration inhibitors. The method for adsorption from claiming inhibiters at the metal surface and the extent of inhibition are already studies The computational systems bring been utilized adequately On finding relationship between theoretically properties and test restriction viability to uniform disintegration [10-.21]. The corrosion resistance was significantly influenced by ultra fine or nano-size grain structures of the alloy as reported in the literature [22-23]. This is incredible realized that oxidation about metal is related to those reduction for hydrogen particles in aqueous acids and the anodic charge flow may be adjusted by $\mathrm{H}_{2}$ molecule diminishing present on the protective film near limited disintegration destinations for instance, pits and stress degradation on the edge of the crack. The transformed hydrogen will penetrate under the metal surface also get collected around these destinations [24, 25].

\section{EXPERIMENTAL DETAILS}

This investigation can be listed as: 1.Specimen preparation . 2 Study of Corrosion rate, 3. Heat Treatment, 4.Hardness measurement, 5. X-Ray Diffraction. We received the Alalloy from supplier as extruded square bar in T6 condition. The specimens were cut in the dimension $15 \mathrm{~mm} \times 10 \mathrm{~mm}$ $\mathrm{x} 10 \mathrm{~mm}$. To analyze the microstructure, initially belt polishing was carried using belt grinder. After the belt grinding, the specimens were polished with emery papers of grades 220, 400, 600, 1000, 1200. Finally. the fine polishing was carried out using diamond paste followed by cleaning with water.

The etching reagent was prepared using $\mathrm{HF}, \mathrm{HCl}, \mathrm{HNO}_{3}$ into water. The etching was performed to the first sample and the microstructure was observed with the help of optical 
microscope at different magnifications. The initial weight $\left(\mathrm{w}_{\mathrm{i}}\right)$ and the surface areas for each specimen were measured and the hardness was measured using Brinell hardness testing machine with $10 \mathrm{~mm}$ diameter ball, $500 \mathrm{kgf}$ load. This investigation has been carried out for solutionized and artificially aged specimens. The solution treatment was performed at $545{ }^{\circ} \mathrm{C}$ for 3 hours 15 minutes. in the muffle furnace. After completion of heating the specimens were taken out from the furnace and quenched into water. The specimens were artificially aged at $185{ }^{\circ} \mathrm{C}$ for 3 hours, 6 hours, 9 hours, 11 hours, and 13 hours respectively. After the completion of aging time intervals specimens were taken out from the muffle furnace and allowed for air cooling. To measure the corrosion rates specimens were taken and the measured. The solution of $0.8 \mathrm{M} \mathrm{H}_{2} \mathrm{SO}_{4}$ was prepared by using $36 \mathrm{M} \mathrm{H}_{2} \mathrm{SO}_{4}$ solution and specimens were immersed into the solution for 0.6 hours, 1.1 hours, 1.58 hours, 2.08 hours and 2.58 hours. After the completion of respective times of intervals the specimen were taken out and dried in the oven at $90-100{ }^{\circ} \mathrm{C}$ for 5 minutes, after drying in the oven, the final weights $\left(\mathrm{w}_{\mathrm{f}}\right)$ were measured. The weight change is calculated and the corrosion rates were measured using the formula. The XRD patterns were obtained by scanning the specimens in $10-90^{\circ}$ with the scanning speed $0.5^{\circ}$ per minute in Bruker's X-Ray Diffractometer.

Table-1: Chemical composition of aluminum alloy.

\begin{tabular}{|c|c|c|}
\hline \multirow{4}{*}{ Alloy } & Chemical element & Weight (wt \%) \\
\hline \multirow{3}{*}{ Al-alloy } & Magnesium (Mg) & 0.91 \\
\cline { 2 - 3 } & Silicon (Si) & 0.55 \\
\cline { 2 - 3 } & Iron (Fe) & 1.12 \\
\cline { 2 - 3 } & Calcium $(\mathrm{Ca})$ & 0.39 \\
\cline { 2 - 3 } & Aluminum & Balance \\
\hline
\end{tabular}

Table 1 shows the EDS analysis of the specimen. The specimen contains more quantity of iron $1.12 \%$ and $0.39 \mathrm{wt}$ $\%$ calcium.

Table -2: The Process variables for corrosion of Al-alloy in $0.8 \mathrm{MH}_{2} \mathrm{SO}_{4}$ at different conditions.

\begin{tabular}{|c|c|c|}
\hline \multirow{2}{*}{$\begin{array}{c}\text { Sample } \\
\text { No. }\end{array}$} & \multicolumn{2}{|c|}{ Immersion time (hrs) } \\
\hline & $\begin{array}{l}\text { Solutionized } \\
\text { specimens }\end{array}$ & Aged specimens \\
\hline 1 & 0.6 & 0.6 \\
\hline 2 & 1.1 & 1.1 \\
\hline 3 & 1.58 & 1.58 \\
\hline 4 & 2.08 & 2.08 \\
\hline 5 & 2.58 & 2.58 \\
\hline
\end{tabular}

Table.-3: Process variables for artificial aging of Al-alloy.

\begin{tabular}{|c|c|c|}
\hline $\begin{array}{c}\text { Sample } \\
\text { No. }\end{array}$ & $\begin{array}{c}\text { Aging temperature } \\
\left({ }^{\circ} \mathrm{C}\right)\end{array}$ & Aging time (hrs) \\
\hline 1 & 185 & 3 \\
\hline 2 & 185 & 6 \\
\hline 3 & 185 & 9 \\
\hline 4 & 185 & 11 \\
\hline 5 & 185 & 13 \\
\hline
\end{tabular}

\section{RESULTS AND DISCUSSION}

\subsection{Microstructure Analysis}

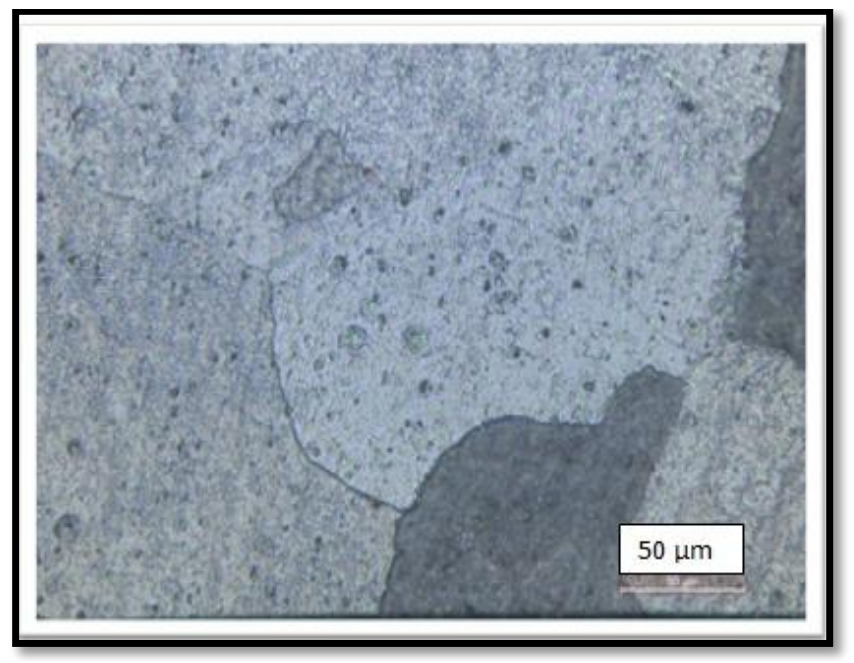

Fig-2: The optical microstructure of Al-alloy without heat treatment.

Fig-2 reveals the microstructure of Al-alloy in industrial T6 condition at $200 \mathrm{X}$ magnification. The revealed structure in figure shows the precipitates of $\mathrm{Mg}_{2} \mathrm{Si}$ inter- metallic compound (dark) in aluminum matrix (bright).

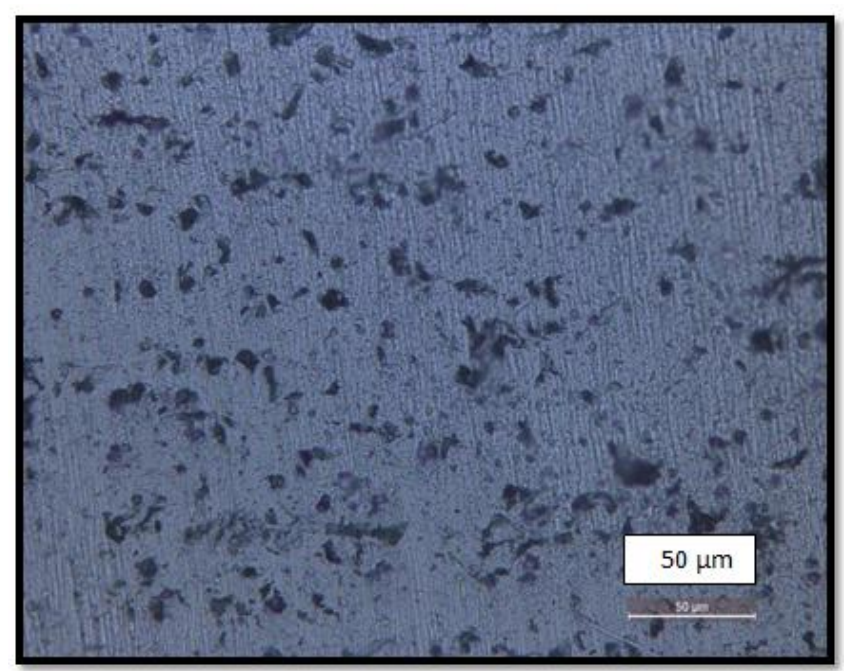

Fig-3: The microstructure of solution treated Al-alloy at 545 ${ }^{\mathrm{o}} \mathrm{C}, 3: 15$ hrs. 
Fig-3 shows the microstructure of solution treated Al-alloy at $545^{\circ} \mathrm{C}$ with the magnification of $100 \mathrm{X}$. The revealed structure in figure shows, the single phase $\alpha$-aluminum microstructure (bright). The dark contrasts visible in the microstructure are second phase particles of iron which is found as impurities.

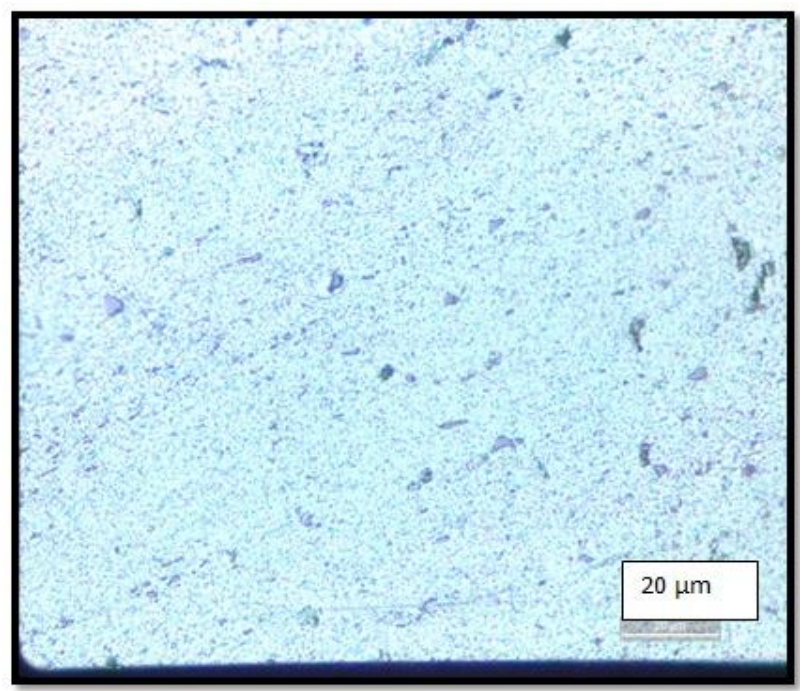

Fig-4: The microstructure of artificially age hardened Alalloy at $185^{\circ} \mathrm{C}, 12 \mathrm{hrs}$.

Fig- 4 shows the microstructure of age hardened Al-alloy at $185^{\circ} \mathrm{C}$ for $11 \mathrm{hrs}$ with the magnification of $100 \mathrm{X}$. The revealed structure in figure shows, the dispersed precipitate of $\mathrm{Mg}_{2} \mathrm{Si}$ inter metallic compound (dark) in aluminum matrix (bright).

\subsection{X-RAY Diffraction Analysis}

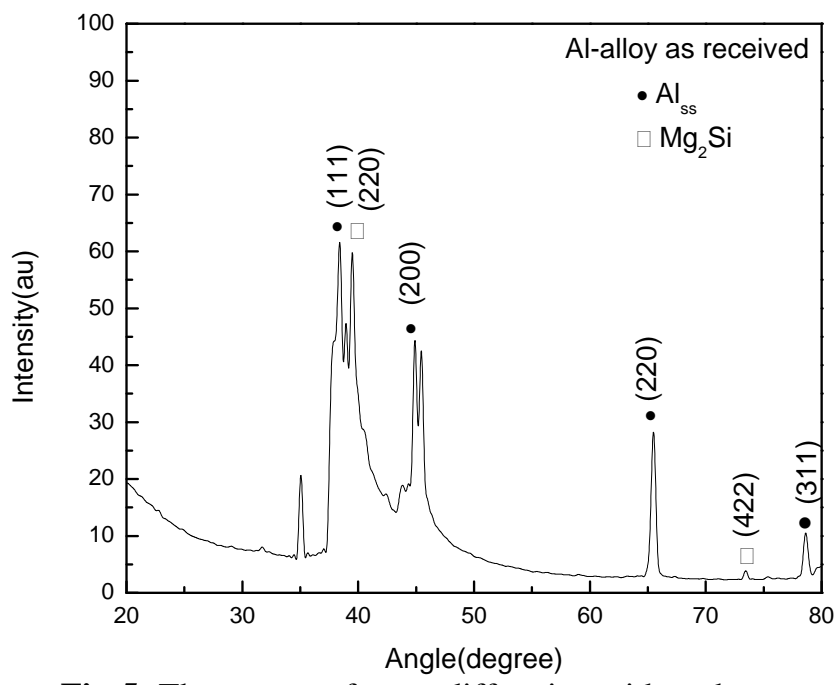

Fig-5: The pattern of x-ray diffraction without heat treatment of Al-Alloy.

Fig 5 is the xrd pattern of as received specimen. The peaks are found at $31.66^{\circ}, 35.04^{\circ}, 38.42^{\circ}, 39.54^{\circ}, 44.79^{\circ}, 45.35$ ${ }^{\circ}, 65.42^{\circ}, 73.44^{\circ}, 78.54^{\circ}$. The aluminum peaks are observed at $38.42^{\circ}, 44.79^{\circ}, 65.42^{\circ}$ and $78.54^{\circ}$. And $\mathrm{Mg}_{2} \mathrm{Si}$ peaks are found at $39.54^{\circ}, 73.44^{\circ}$ and $78.54^{\circ}$.

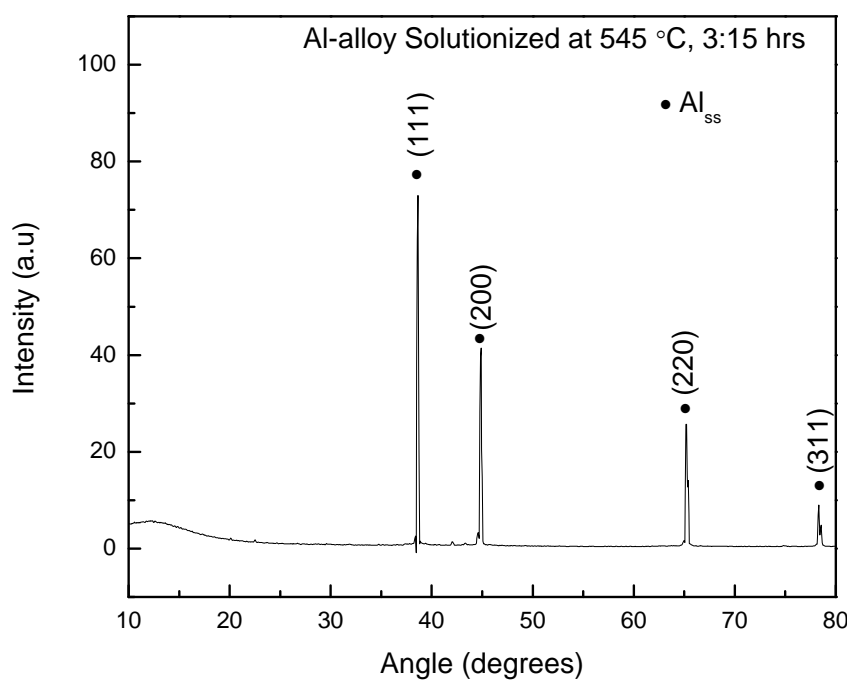

Fig-6: X-Ray Diffraction pattern of Al-alloy, solution treated at $545^{\circ} \mathrm{C}$ for $3: 15 \mathrm{hrs}$.

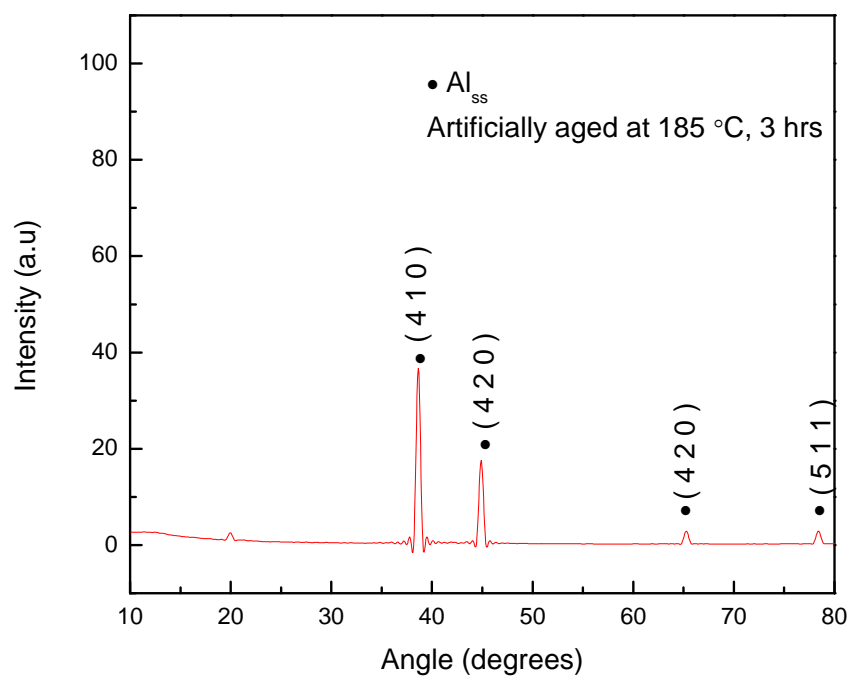

Fig-7: X-Ray Diffraction pattern of Al-alloy, artificially aged at $185^{\circ} \mathrm{C}, 3 \mathrm{hrs}$.

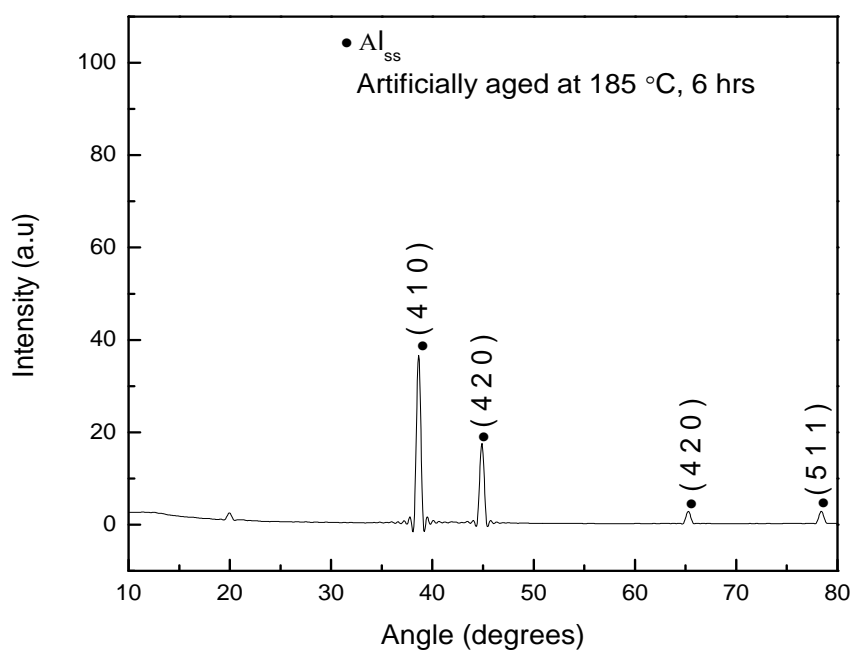

Fig-8: X-Ray Diffraction pattern of Al-alloy artificially aged, at $180^{\circ} \mathrm{C}, 6 \mathrm{hrs}$. 


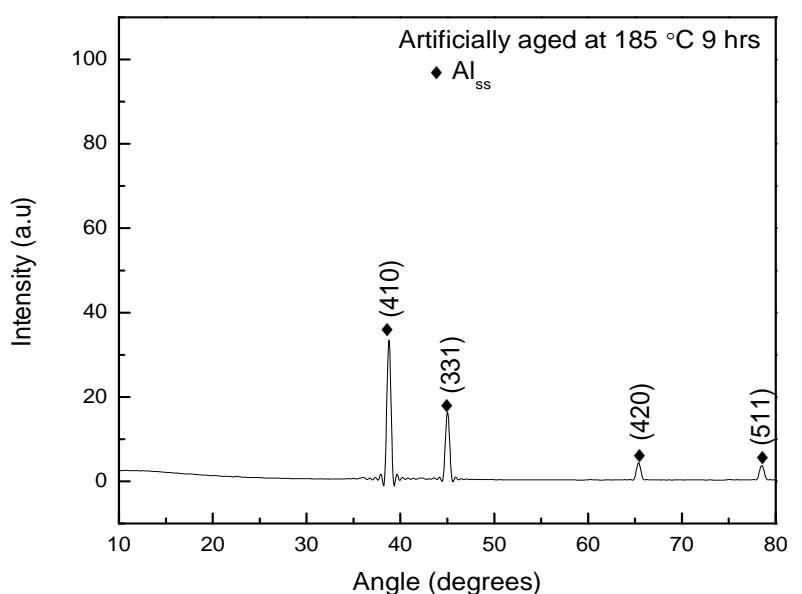

Fig-9: X-Ray Diffraction pattern of Al-alloy artificially aged, at $180{ }^{\circ} \mathrm{C}, 9 \mathrm{hrs}$.

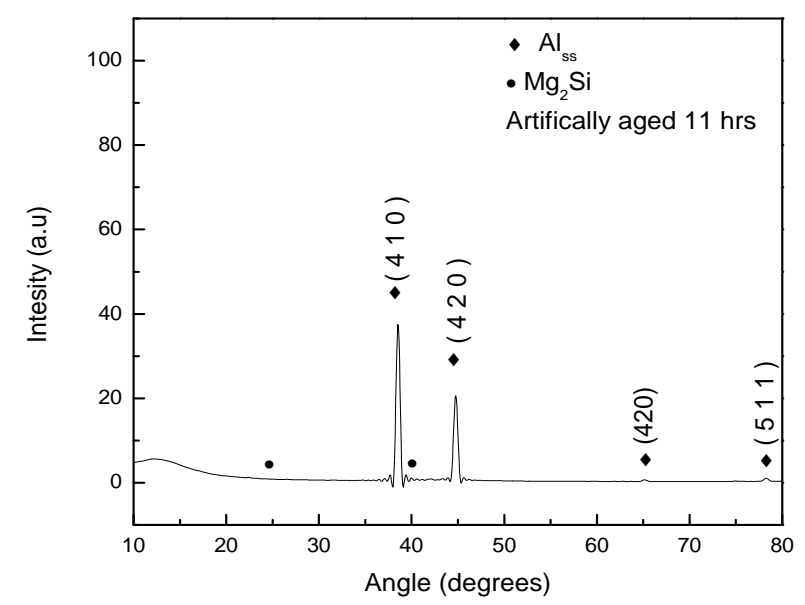

Fig-10: X-Ray Diffraction pattern of Al-alloy artificially aged, at $185^{\circ} \mathrm{C}, 11 \mathrm{hrs}$.

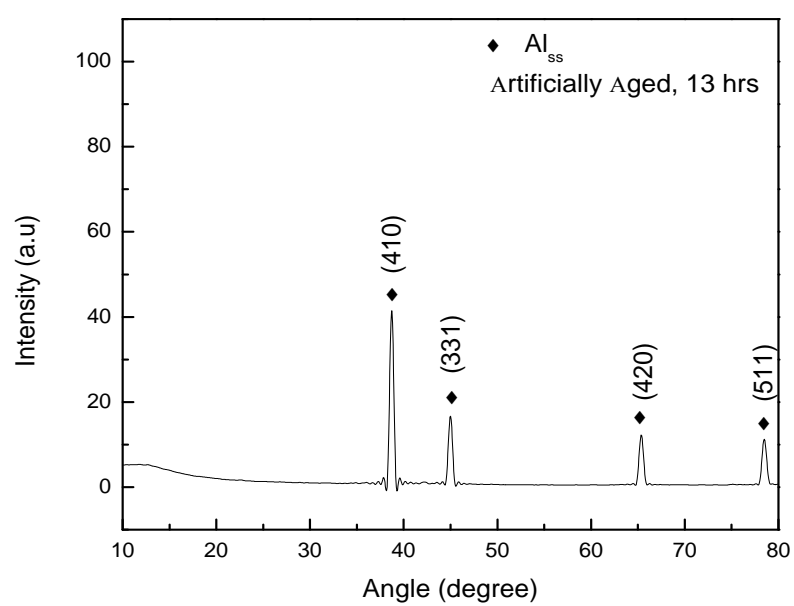

Fig-11: X-Ray Diffraction pattern of Al-alloy artificially aged, at $185^{\circ} \mathrm{C}, 13 \mathrm{hrs}$

Fig 5-11 shows X-Ray Diffraction pattern of Al-alloy at different conditions. It shows four major peaks of aluminum solid solution. The highest intensity peak is observe at (410) plane with an angle $38.72^{\circ}$. Other three peaks are found at $44.96^{\circ} 65.3^{\circ}$ and $78.4^{\circ}$ respectively. The precipitate $\left(\mathrm{Mg}_{2} \mathrm{Si}\right)$ peaks are found at $24.4^{\circ}$ and $40.2^{\circ}$ respectively.
Table-4: Hardness values measured on Brinell hardness tester.

\begin{tabular}{|c|c|c|}
\hline Sample No. & Aging time (min.) & Hardness (BHN) \\
\hline 1 & 180 & 27 \\
\hline 2 & 360 & 32 \\
\hline 3 & 540 & 36 \\
\hline 4 & 660 & 50 \\
\hline 5 & 780 & 29 \\
\hline
\end{tabular}

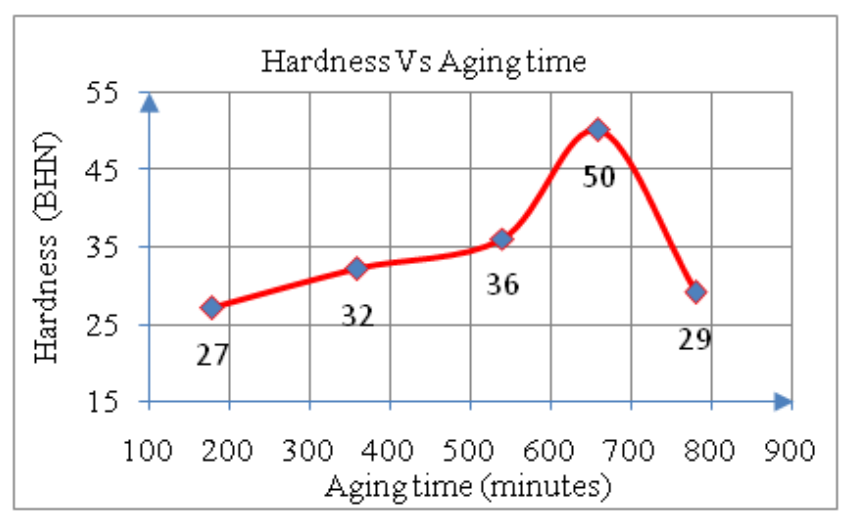

Fig-12: The hardness vs artificially aging plot of Al-alloy aged at $185^{\circ} \mathrm{C}$.

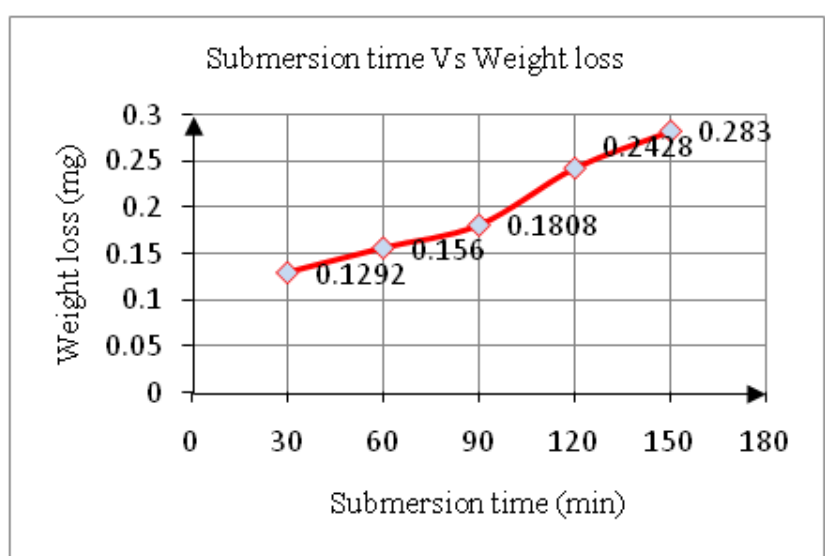

Fig-13: The weight loss vs. Submersion time plot of Alalloy into $0.8 \mathrm{M} \mathrm{H}_{2} \mathrm{SO} 4$ without heat treatment.

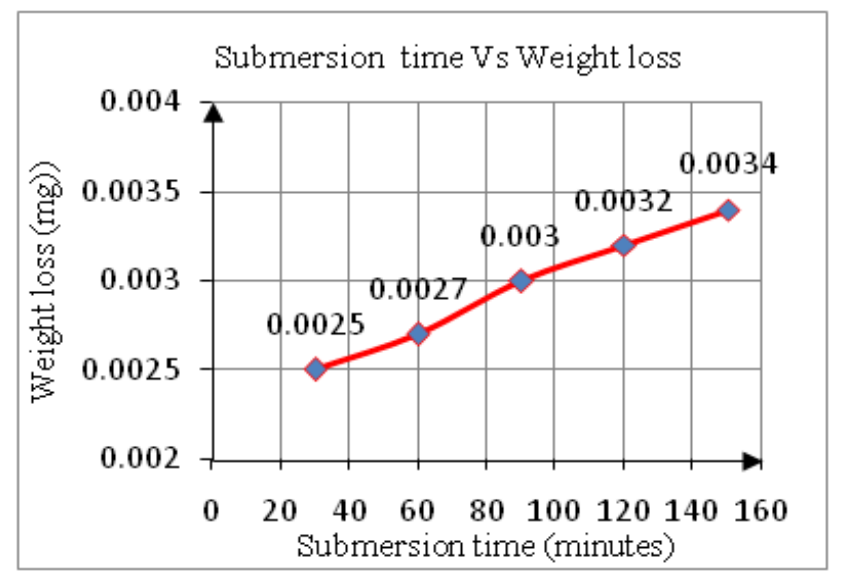

Fig-14: The weight loss vs Submersion time plot of solution treated Al-alloy submersed into $0.8 \mathrm{M} \mathrm{H}_{2} \mathrm{SO} 4$. 


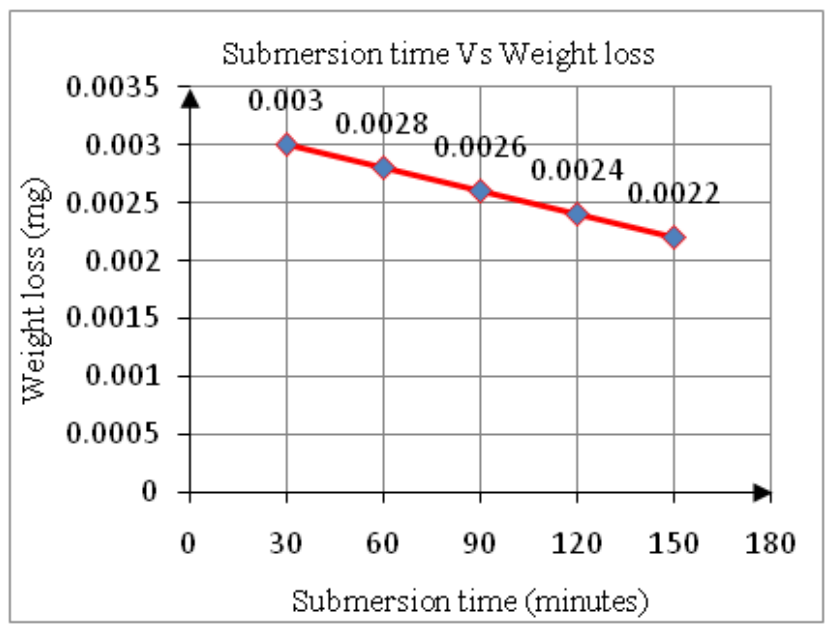

Fig-15: The weight loss vs submersion time plot of artificially aged $\mathrm{Al}$-alloy submersed into $0.8 \mathrm{M} \mathrm{H}_{2} \mathrm{SO} 4$.

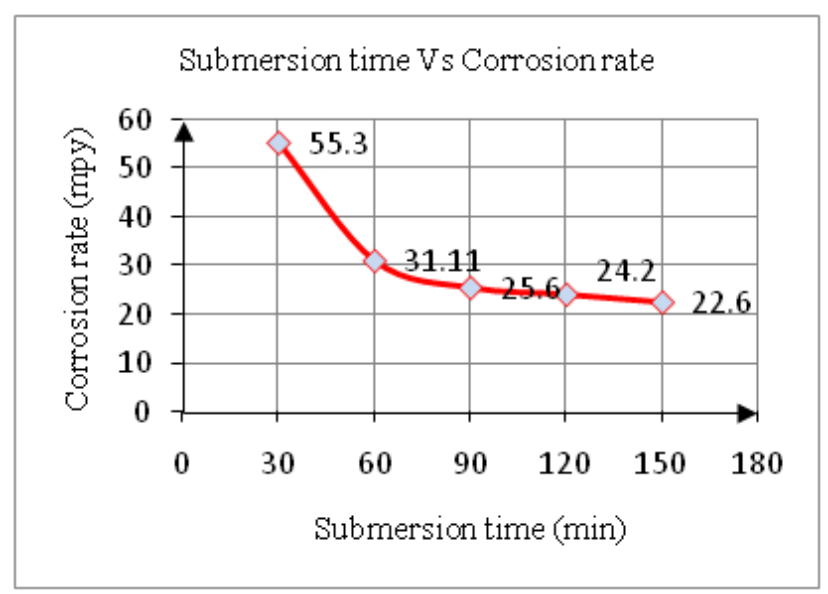

Fig-16: Submersion Time Vs corrosion rate plot for specimens without heat treatment..

Fig $13 \&$ fig. 16 represents the mass reduction and rate of degradation plots for the without treated specimens submersed in $0.8 \mathrm{M}, 2.3$ (wt \%) $\mathrm{H}_{2} \mathrm{SO}_{4}$ solution. Fig 13. shows that as immersion time increases weight loss also increases. Fig 16 shows that there was drop in the rate of degradation with the raise of time. This is because of the formation of protective layer on the whole submersed surface area of the sample. The specimens are solutionized and artificially aged. The hardness values of artificially aged specimens are found increasing with increase of aging time. This is because of formation of precipitate $\left(\mathrm{Mg}_{2} \mathrm{Si}\right)$ which is coherent with the matrix. As precipitates grow, it creates strain in the matrix material. The hardness increases by increase in amount of precipitate. But the hardness increases up to certain level after that hardness starts decreasing with increasing aging time. The specimen which was aged for 11 hours has highest hardness value of $50 \mathrm{BHN}$.

The precipitates restrict the dislocation movements. According to the critical radius phenomena, in precipitate growing, above the critical radius precipitates are stable and below the critical radius most of the precipitates will be unstable and will dissolve at a higher aging temperature, precipitates of larger sizes are

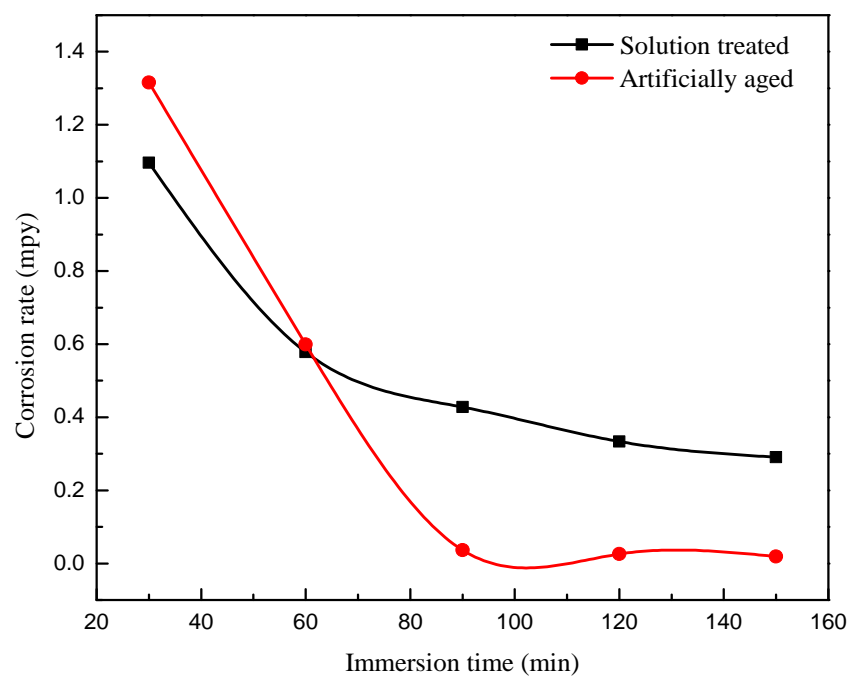

Fig-17: Immersion time Vs corrosion rate plots of Al-alloy for solution treated (black) and artificially aged (red).

formed due to the large critical radius. For longer aging time, the precipitate particles become coarser resulting in loss of coherency. Hardness decreases because of loss coherency between precipitate particles and matrix. There is unfaltering furthermore progressive drop in the rate of degradation of the solutionized sample inferring that there was steadiness of protective layer development. The drop in rate of degradation (Fig. 17 ) could likewise be ascribed to the way that, the alloy on quenching holds some $\mathrm{Mg}_{2} \mathrm{Si}$, iron and Calsium in the aluminum matrix. So, this solid solution exhibit better strength due to retained $\mathrm{Mg}_{2} \mathrm{Si}$ and ironsecond phase in the aluminum matrix. The alloy contains 1.12 (wt \%) iron which is more than the solubility limit of iron in aluminum. So iron appears as $(\mathrm{AlFeCa})$ second phase particle. Consequently, the drop in rate of degradation is found decreasing for longer submersion time of span into $0.8 \mathrm{MH}_{2} \mathrm{SO}_{4}$. For artificially aging, which is to a great extent termed as precipitation hardening, the hardness is found increasing with increased the amount coherent precipitate by accelerating the diffusion rates of $\mathrm{Mg}$ and $\mathrm{Si}$. The corrosion behavior of the artificially aged samples showed (Fig-17, red color plot) that for the immersion of 0.6 hours, 1.1 hours, 1.58 hours the corrosion rate is sufficiently lowered because of protective layer formation and stabilized after 1.5 hours. It showing that the heat treated Al-alloy can be suggested for acidic atmosphere. We analyzed the XRD patterns of solution treated and artificially aged specimen. The XRD patterns show peaks of aluminum solid solution and $\mathrm{Mg}_{2} \mathrm{Si}$ precipitates.

\section{CONCLUSIONS}

1. The impact of degradation on heat treated Al-alloy submerged in $0.8 \mathrm{M}$ sulfuric acid corrosive arrangement has been effectively contemplated.

2. The outcomes acquired demonstrated that the degradation vulnerability of heat treated Al-alloy was observed to be lower than the solution treated Al-alloy as can be seen from the slant of the plot.

3. It was additionally noticed that the protective layer formed on the surface of sample was adequately steady 
which contributed in the drop of rate of degradation on the heat treated alloy. For that reason, the utilizations of Al-alloy aged for 0.6 hours and 1.1 hours is proposed for acidic environment

4. The optimum age hardening is achieved of the specimen that is aged at $185^{\circ} \mathrm{C}$ for 660 minutes of aging time. It showed that 660 minutes of aging time can exhibit a maximum hardness of 50 BHN measured on Brinell hardness tester.

5. The highest hardness can be achieved by placing a large amount of closely spaced small and rounded precipitates $\left(\mathrm{Mg}_{2} \mathrm{Si}\right)$, which are coherently dispersed throughout the alloy.

6. The lower value of hardness is found $29 \mathrm{BHN}$ at 780 minutes, the softening has taken place due to the precipitate coarsening led to loss in coherency between precipitate and matrix.

7. The XRD patterns obtained from the solution treated and artificially aged at $185{ }^{\circ} \mathrm{C}$ for different times of intervals specimen are showing the peaks of aluminum solid solution and $\mathrm{Mg}_{2} \mathrm{Si}$.

\section{REFERENCES}

[1] J.R Devis, "Alloying understanding the basics", ASM International, (2001).

[2] L. Hong, Z. Gang, L. Chun. Ming, L. Zuo, Trans. Nonferr. Metals Soc. China 16 (2006), p. 376-381.

[3] W.S. Miller, L. Zhuang, J. Bottema, A.J. Witterbrood, P.D. Smet, A. Haszler, A. Vieregge, Mater. Sci. Eng. A 280 (2000), p. 37-49.

[4] T.D. Burleigh, Corrosion 47 (1991), p. 89.

[5] F.D. Wall, G.E. Stoner, Corros. Sci. 39 (1997), p. 835.

[6] A. Conde, B.J. Fernandez, J.J. De Damborenea, Corros. Sci. 40 (1998), p. 91.

[7] M.R. Bayoumi, Eng. Fract. Mech. 54 (1996), p. 879.

[8] D. Najjar, T. Magnin, T.J. Warner, Mater. Sci. Eng. A 238 (1997), p. 293.

[9] Directive 2002/95/EC of the European Parliament and the Council on the Restriction of the Use of Certain Hazardous Substances in Electrical and Electronic Equipments, Official Journal of the European Union, January 27, L 37/19, 2003.

[10] J. Vosta, J. Eliasek, Corros. Sci. 11 (1971), p. 223.

[11] A. Chakrabarti, Br. Corros. J. 19 (1984), p. 124.

[12] P.G. Abdul. Ahad, S.H.F. Al-Madfai, Corrosion 45 (1989), p.978.

[13] F.B. Growcock, Corrosion 45 (1989), p. 1003.

[14]F.B. Growcock, W.W. Freiner, P.A. Andreozzi, Corrosion 45 (1989), p. 1007.

[15] J.M. Costa, J.M. Lluch, Corros. Sci. 24 (1984), p. 929.

[16] P. Kutej, J. Vosta, M. Bartos, Proc. Eighth Eur. Symp. Corros. Inhibitors (8SEIC), Ann. Univ. Ferrara, Italy 10 (1995), p. 896.

[17] I. Lukovits, E. Kalman, I. Baka, I. Felhasi, J. Teledgi, Proc. Eighth Eur. Symp. Corros. Inhibitors (8SEIC), Ann. Univ. Ferrara, Italy 10 (1995), p. 543.

[18] I. Lukovits, T. Kostalanyi, E. Kalman, G. Palinkos, Conference Corrosion 99, San Antonia, TX, USA 1999 p. 565.
[19] G.H. Awad, A.N. Asad, A.M. Abdel Gaber, S.S. Masud, Zashchita Metallov, 33 (1997) p. 6,565.

[20] G. Bereket, C. Ogretir, A. Yurt, J. Mol. Struct. (THEOCHEM) 571 (2001), p. 139.

[21]G. Bereket, C. Ogretir, E. Hur, J. Mol. Struct. (THEOCHEM) 578 (2001), p. 79.

[22] M.K. Chung, Y.S. Choi, J.G. Kim, Y.M. Kim, J.C. Lee, Mater. Sci. Eng.A 366 (2004), p. 282-291.

[23] D. Song, A. Ma, J. Jiang, P. Lin, D. Yang, Trans. Nonferr. Metals Soc. China 19 (2009), p. 1065-1070.

[24] L.J. Qiao, W.Y. Chu, C.M. Hsiao, J. Scripta Metall. 22 (1988), p. 627.

[25] L.J. Qiao, J.L. Luo, X. Mao, J. Mater. Sci. Lett. 16 (1997), p. 518.

\section{BIOGRAPHIES}

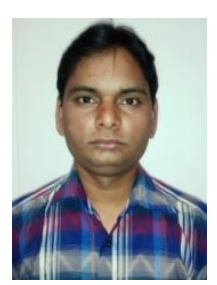

I Completed B.Tech in Metallurgical and Materials Engineering from National Institute of Technoloy (NIT) Durgapur west Bengal (2010) and M.Tech in Materials Science and Engineering from Indian Institute of Technology (IIT), Kanpur Uttar Pradesh (2013) and worked around one year in steel industry (CCP-Operations, 2010-2011). Year 2013 onwards, I am working as Lecturer in Metallurgical and Materials Engineering Department of Rajiv Gandhi University of Knowledge Technologies (RGUKT) IIIT A P Nuzvid India. My area of research interest is physical metallurgy, alloy design, brazing and development of brazing fillers.

saropya@gmail.com, schand@rgukt.in (author1)

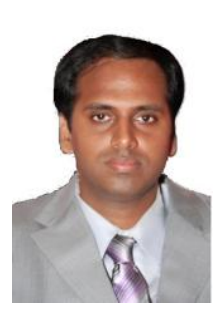

I (Madhusudhan D), completed under graduation in the department of Chemical Engineering at Andhra University, Vizag. There after completed MS in Chemical Engineering as well as ME in Materials Science Engineering (both in USA). Worked research associate in the field of Polymeric materials and nanotechnology. I have been working as a faculty in Dept. of Metallurgical and Materials Engg. (RGUKT) since the last five years. My main area of research interests is computational materials science.I handled many undergraduate B.tech projects in in the department of Metallurgical and Materials Engineering at RGUKT,

email.madhudasary@gmail.com (Author 2) 